\title{
THE PRESERVATION OF ERYTHROCYTES LEFT OVER FROM PLASMA PREPARATION ${ }^{1}$
}

\author{
By MAX M. STRUMIA, ALTON D. BLAKE, JR., AND WILLJAM A. WICKS \\ WITH THE TECHNICAL ASSISTANCE OF MISS KATHERINE DONNELLY, \\ MISS MARGARET DOLAN, AND MISS LOUISE COLWELL \\ (From the Laboratory of Clinical Pathology of the Bryn Mawr Hospital, \\ Bryn Mawr, Pennsylvania)
}

(Received for publication August 31, 1946)

The practice of transfusion of red cells left over from preparation of plasma has gained some popularity ( 1 to 11 ). Whether or not this practice will ever become an accepted and widespread procedure and what its practical merits are need not be discussed at this time.

It is obvious that the use of red cells left over from plasma preparation' is possible only when plasma is separated after a relatively short period of time. It has been the practice to resuspend the red cells in crystalloid solutions of which the two most popular have been physiological salt solution (5) and 10 per cent corn syrup (12). Since the red cells normally are immersed in a colloidal protein fluid, it is natural to expect a priori a better preservation of the erythrocytes when maintained in a protein colloidal medium. This has been found to be true in the experimental work reported here. Ross (13) has shown good preservation of red cells left over from plasma preparation when the cells are simply stored in the remaining plasma. In this paper it will be shown that globin considerably improves the preservation of red cells and that its use as a resuspension medium for red cells is practical. This does not justify at present the conclusion that for optimal preservation of erythrocytes it is necessary to add any diluting fluid to the packed cells left over after the separation of plasma.

\footnotetext{
1 This paper is the 20th of a series on blood, plasma, and plasma substitutes from the Laboratory of Clinical Pathology of the Bryn Mawr Hospital. The work described in this paper was done under a contract recommended by the Committee on Medical Research, between the Office of Scientific Research and Development and the Bryn Mawr Hospital, and with the aid of the Bryn Mawr Research Foundation.
}

\section{PRESERVATION OF ERYTHROCYTES IN PHYSIO- LOGICAL SALT SOLUTION}

This resuspension medium has been the most commonly used. The maximum recommended period of preservation is from 5 to 6 days (10) at icebox temperature. We have found that the preservation of fresh red cells in physiological saline solution at $4^{\circ} \mathrm{C}$. for more than a few hours very greatly reduces the post-transfusion survival of the red cells. Injection of 200 to $450 \mathrm{ml}$. of such cells in humans (corresponding to 500 to $1,000 \mathrm{ml}$. of whole blood) is followed in the majority of cases by hyperbilirubinemia and greatly increased bile pigment output.

In these experiments the blood was collected in plain sodium citrate solution ( $50 \mathrm{ml}$. of 4 per cent sodium citrate for each $500 \mathrm{ml}$. of blood) and immediately stored at $4^{\circ} \mathrm{C}$. The plasma was separated after centrifugation and in any case within 36 hours from the time of collection. The red cell residue was immediately mixed with .9 per cent sodium chloride solution, chilled, in an amount approximately equivalent to that of the plasma removed. The red cell-saline mixture was immediately placed at $4^{\circ} \mathrm{C}$. and was maintained there until time for use. Grouping, $\mathrm{Rh}$ typing and cross matching were carried out as usual. A typical case is reported here.

The patient was a man, aged 54 , white. This patient was chosen because hematological studies, including a bone marrow biopsy and total bile pigment output determinations, had shown that the sole defect was a greatly reduced normoblastic activity of the bone marrow, from cause unknown. On first admission to the hospital on May 23, the hemoglobin concentration was 2.3 grams per cent with a reticulocyte count of .1 per cent and a total volume of circulating packed erythrocytes of only $280 \mathrm{ml}$. The patient belonged to the $B$ group and was $R h$ negative. Sixteen whole blood transfusions of compatible blood, each containing on an average of $450 \mathrm{ml}$. of blood, were given to this patient over a 53-day period. The patient appeared to tolerate well the transfusions of whole citrated blood, showing no hyperbilirubinemia nor any other signs of reaction. At the time of his discharge on July 12 the hemoglobin concentration was 9 grams per cent. The 
patient was readmitted to the hospital on July 25 and at this time the hemoglobin concentration was 6.8 grams per cent, with 2 reticulocyte count of .1 per cent. From blood volume measurements it is estimated that on July 12 the patient had a volume of packed erythrocytes of 986 $\mathrm{ml}$. On July 29 the hemoglobin concentration was 6.1 grams per cent and the volume of erythrocytes was 745 $\mathrm{ml}$. or a decline of $241 \mathrm{ml}$. of packed erythrocytes in 17 days with an average loss of about $14 \mathrm{ml}$. of packed erythrocytes daily. This loss is rather low and indicates good preservation of the transfused erythrocytes. Repeated serum bilirubin determinations showed a concentration of $.8 \mathrm{mgm}$. per cent with a low urobilin output. This patient was given on July $29,791 \mathrm{ml}$. of packed erythrocytes, of $\mathrm{O}$ group, $\mathrm{Rh}$ negative, separated from plasma within 18 hours of collection after centrifugation, mixed with chilled saline solution to make a total volume of $1,071 \mathrm{ml}$. and maintained at $4^{\circ} \mathrm{C}$. for 72 hours.

Following the transfusion of the resuspended erythrocytes, the patient had a hemolytic reaction, with discomfort in the lower abdomen, passage of red urine, containing hemorrhagic casts, high urobilin concentration in the urine and a rise in the serum bilirubin to over 14 mgm. per cent. In 48 hours the patient was entirely well from the reaction (see Figure 1). On August 2, the hemoglobin concentration was 6.9 grams per cent and the volume of packed erythrocytes $758 \mathrm{ml}$., indicating practically a complete loss of the injected mass of erythrocytes. On August 2, the patient received $305 \mathrm{ml}$. of packed erythrocytes as $896 \mathrm{ml}$. of whole citrated blood

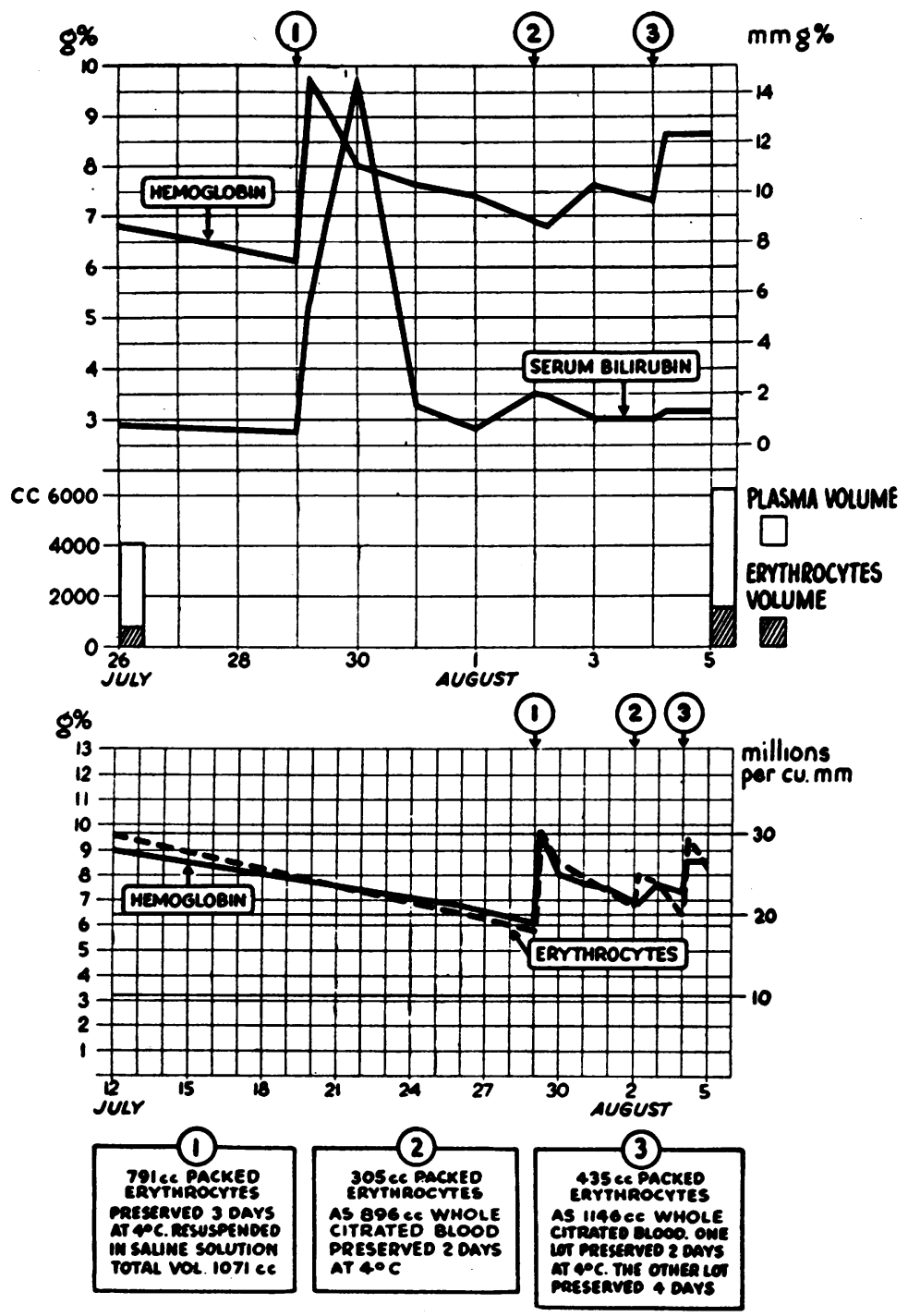

Fig. 1. The Effect of Transfusions on the Hemoglobin, Serum Bilirubin aNd Blood Volume 
preserved for 2 days. On August 4, $435 \mathrm{ml}$. af packed erythrocytes as $1,146 \mathrm{ml}$. of whole citrated blood were given to the patient, one lot of blood being 2 days old and the other 4 days old. The patient had no apparent reaction to the transfusion. On August 5, the hemoglobin concentration was 8.6 grams per cent and the measured volume of packed erythrocytes was $1,538 \mathrm{ml}$. with an apparent gain of $780 \mathrm{ml}$. of packed erythrocytes. This represents for the period of time of observation a good survival of the injected red cells, the total amount of injected red cells having been $740 \mathrm{ml}$. As can be seen from Figure 1 , the transfusion of whole citrated blood preserved from 1 to 4 days at $4^{\circ} \mathrm{C}$. was not followed by a notable increase in the serum bilirubin level.

\section{IN VITRO COM PARATIVE STUDIES ON THE PRESERVA- TION OF ERYTHROCYTES IN 4 PER CENT GLOBIN SOLUTION, SALT SOLUTION AND 10 PER CENT CORN SYRUP}

The effect of a 4 per cent globin solution on the preservation of resuspended erythrocytes has been studied both in vitro and in vivo. The studies in vitro included $\mathrm{pH}$ determination, mean corpuscular volume, osmotic resistance, and the hemoglobin concentration in the supernatant fluid.

The addition of globin to a suspension of erythrocytes in salt solution does not appreciably alter the cell preservation. However, when the erythrocytes are suspended in a sodium citratedextrose solution, the globin exerts a definite beneficial effect on the preservation. We are well aware that the choice of crystalloids and their relative concentration as well as the final $\mathrm{pH}$ of the solution employed here are probably far from the ideal. We are, however, reporting a typical experiment to show the change which the addition of globin produces in the preservation of erythrocytes.

Five hundred $\mathrm{ml}$. of blood from an adult healthy donor were collected in $60 \mathrm{ml}$. of a 4 per cent sodium citrate solution, chilled. The sodium citrate solution was chosen because it was the same used by the Red Cross bleeding centers. The blood was allowed to remain for 18 hours at $4^{\circ} \mathrm{C}$. It was then centrifuged for 45 minutes at 1,800 times gravity. The plasma was carefully removed, leaving only about $20 \mathrm{ml}$. of it with the packed red cells. The red cell sediment was then carefully mixed with the remaining plasma, and by means of a sterile calibrated cylinder it was divided into aliquots. Each of these aliquots was mixed with an equal part of the various preserving fluids. The composition of these is given in the following table:
Salt solution:

Sodium chloride

.9 per cent

A.C.D. solution :

Sodium citrate (trisodium, dihydric)

Citric acid (monohydric)

Dextrose (anhydrous)

Distilled water (pyrogen-free)

1.66 grams

0.59 gram

3.75 grams

$125 \mathrm{ml}$.

Corn syrup: 10 per cent sterile solution as obtained from Schering, Glatz Company.

Dextrose-citrate:

Dextrose (anhydrous)

2.4 grams

Sodium citrate (trisodium dihydric) 1.9 grams Water

$100 \mathrm{ml}$.

Globin-dextrose-citrate:

$\begin{array}{ll}\text { Globin } & 4 \text { grams } \\ \text { Dextrose (anhydrous) } & 2.4 \text { grams } \\ \text { Sodium citrate (trisodium, dihydric) } & 1.9 \text { grams } \\ \text { Water } & 100 \mathrm{ml} .\end{array}$

After mixing, the various red cell suspensions were cultured and divided into $10-\mathrm{ml}$. aliquots in hard glass, rubber-stoppered bottles. These were immediately placed at $4^{\circ} \mathrm{C}$. and maintained at this temperature until the time of study.

The determination of the osmotic resistance was made by a modification of the technique suggested by Parpart (14) ; the mean corpuscular volume was done in duplicate; the $\mathrm{pH}$ was determined with a Beckman apparatus. The hemoglobin of the supernatant fluid was done after thorough mixing of the sample followed by centrifugation. All samples were cultured again at the end of the stated period of time.

\section{ANALYSIS OF RESULTS}

Mean corpuscular volume. There was swelling in all of the solutions used. This swelling was minimal with the citrate-dextrose solution and with the salt solution. It was maximal with the 10 per cent corn syrup (see Figure 2). By the fifth day of preservation and continuing on to the end of the experiment, there was a shrinkage of the cells to within the normal range, except for the A.C.D. solution in which there was an excessive shrinkage followed by a progressive swelling to normal size. The addition of globin to the dextrose-citrate solution appears to have a definite effect on the rate and range of volume changes.

Mean osmotic resistance of resuspended erythrocytes (fragility). Except for the sodium chloride, the mean osmotic resistance is considerably increased. This increase is minimal with the 


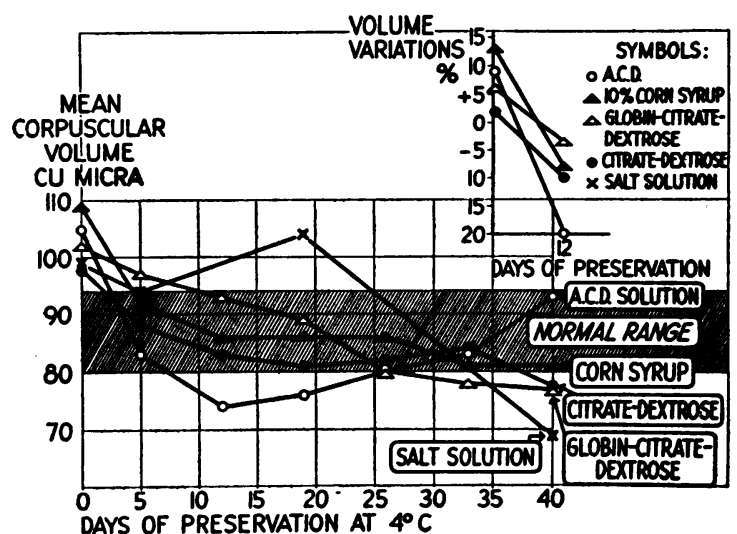

Fig. 2. Mean Corpuscular Volume

globin citrate-dextrose solution, and it is maximal with the A.C.D. solution. The addition of globin to the citrate-dextrose solution definitely effects a change in osmotic resistance, maintaining it nearer to the normal change (see Figure $3)$.

$p H$ variations. The variations of the $\mathrm{pH}$ of the original solutions of the supernatant fluid are indicated in the following table:

\begin{tabular}{|c|c|c|c|c|c|}
\hline & A.C.D. & $\begin{array}{l}10 \text { per } \\
\text { cent corn } \\
\text { syrup }\end{array}$ & $\begin{array}{c}\text { Salt } \\
\text { solution }\end{array}$ & $\begin{array}{l}\text { Dex- } \\
\text { trose- } \\
\text { citrate }\end{array}$ & $\begin{array}{l}\text { Globin- } \\
\text { dextrose- } \\
\text { citrate }\end{array}$ \\
\hline $\begin{array}{l}\mathrm{pH} \text { of } \\
\text { original } \\
\text { solution }\end{array}$ & 5.04 & 4.22 & 5.52 & 6.05 & 7.71 \\
\hline $\begin{array}{l}\text { pH of } \\
\text { supernatant } \\
\text { fluid }\end{array}$ & & . & & & \\
\hline $\begin{array}{r}0 \\
5 \\
12 \\
19 \\
26 \\
33 \\
40\end{array}$ & $\begin{array}{l}6.0 \\
6.0 \\
6.0 \\
6.0 \\
6.0 \\
6.0 \\
6.0\end{array}$ & $\begin{array}{l}7.3 \\
7.5 \\
7.6 \\
7.6 \\
7.6 \\
7.5 \\
7.4\end{array}$ & $\begin{array}{l}7.4 \\
7.7 \\
7.4\end{array}$ & $\begin{array}{l}7.1 \\
7.05 \\
7.05 \\
7.0 \\
7.0 \\
7.0 \\
7.0\end{array}$ & $\begin{array}{l}7.2 \\
7.4 \\
7.2 \\
7.2 \\
7.25 \\
7.2 \\
7.2\end{array}$ \\
\hline
\end{tabular}

Hemoglobin concentration in the supernatant fluid. To obtain this datum, the erythrocyte suspensions were thoroughly mixed and centrifuged; the determination was made by the micro method reported separately (15). The hemoglobin concentration in the A.C.D. solution, in the citrate-dextrose solution, and in the globin citrate-dextrose is comparable. It is definitely less in the 10 per cent corn syrup and increases much more rapidly in the salt solution. These data appear of little significance (see Figure 4).

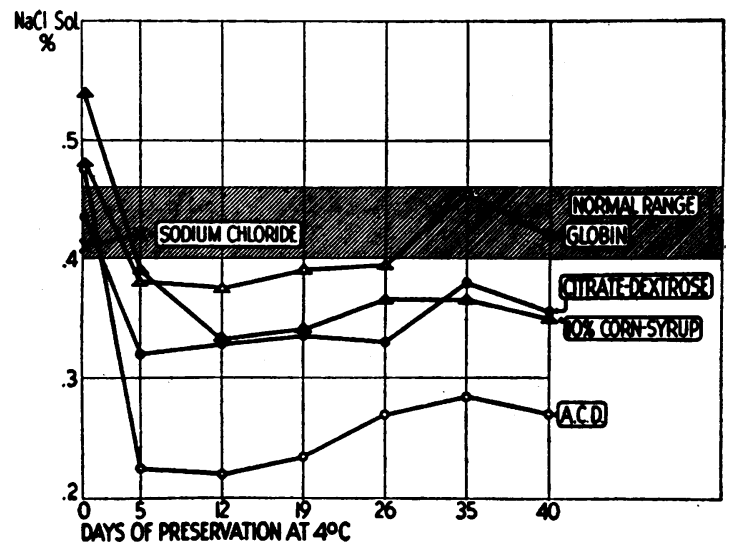

Fig. 3. Mean Osmotic Resistance of Resuspended ERythrocytes (Fragility)

POST-TRANSFUSION SURVIVAL OF ERYTHROCYTES SUSPENDED IN 4 PER CENT GLOBIN SOLUTION BY THE RADIOACTIVE IRON TECHNIC

\section{Clinical observations}

Studies on the in vivo survival of erythrocytes resuspended in globin solution by means of the iron isotope technic have been carried out (see Figure 5).

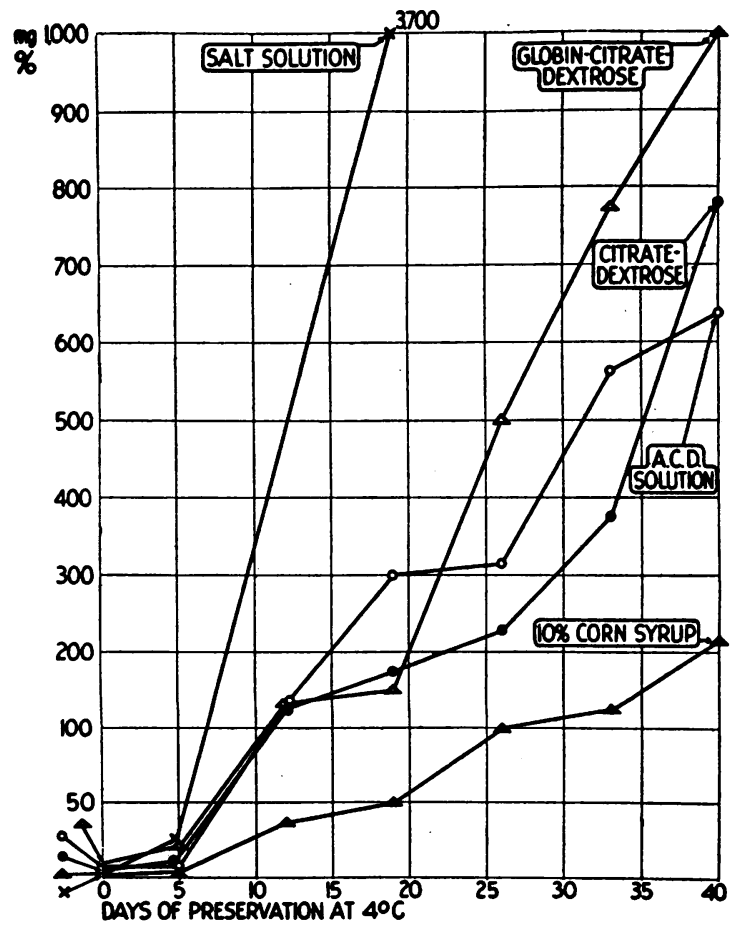

Fig. 4. Hemoglobin Concentration in the Supernatant Fluid 


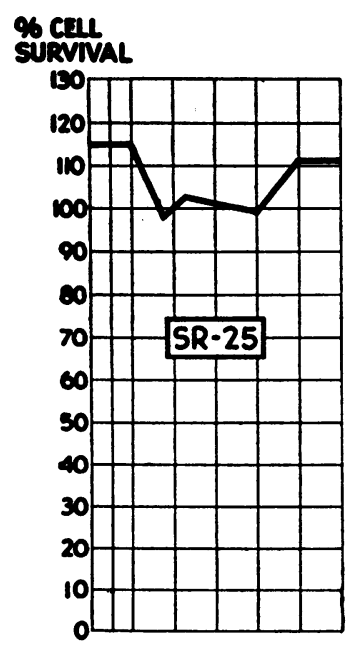

FRESH

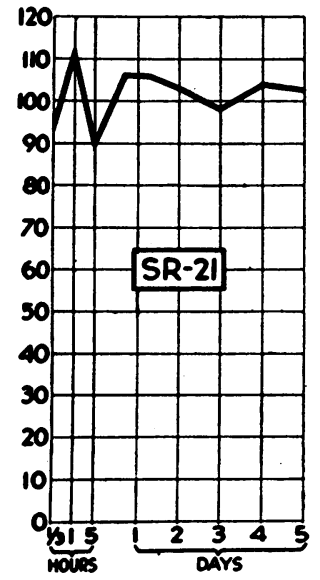

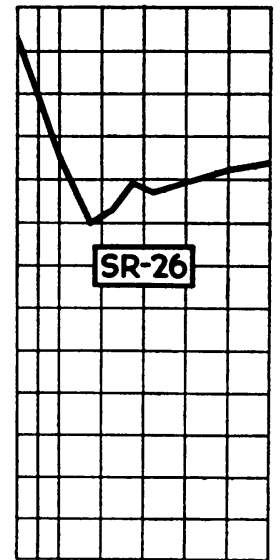

7 DAYS OLD

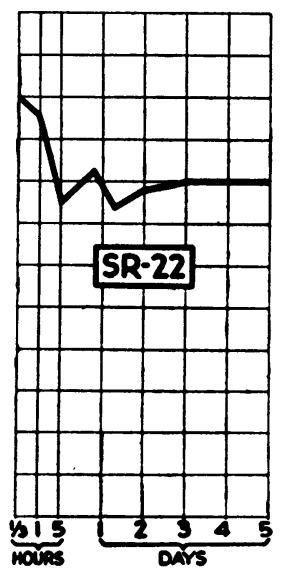

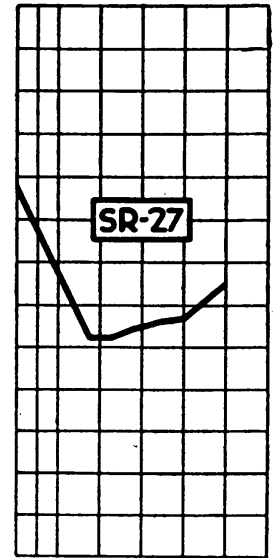

17 DAYS OLD

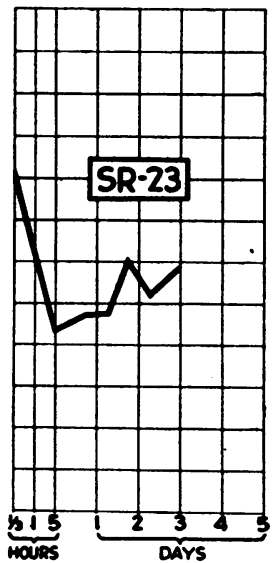

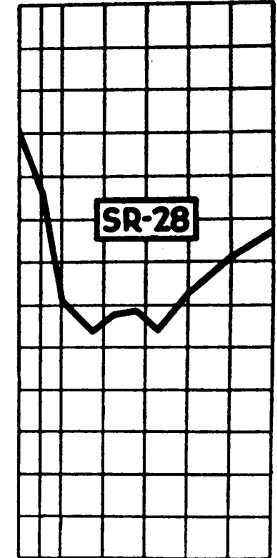

21 DAYS OLD

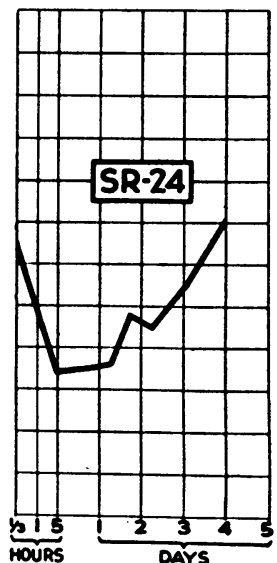

Fig. 5. Survival of Erythrocytes Resuspended in Citrate Dextrose-Globin Solution Determined by the Iron Isotope TeChnic

The survival of the transfused cells is 75 to 80 per cent up to 7 days of preservation and 50 per cent or better up to 15 days. It is of very great importance to note that:

(I) In our experience, using as recipients patients rather than healthy males as in the experiments reported by Gibson, the preservation of cells as determined by the iron isotope technic is generally poorer than that found by other observers, regardless of the preserving fluid employed.

(2) Whereas with all of the preserving fluids so far used the rate of cell deterioration is definitely accelerated, as the preservation is prolonged, with addition of globin it becomes definitely slower.
It is probable that an initial damage occurs and that a better choice of crystalloids to make the fluid iso-osmotic may very materially improve the preserving properties of the globin solution.

Figure 6 affords a comparison of the rate of preservation of erythrocytes resuspended in globin dextrose-citrate and of whole blood preserved in A.C.D. and glucose-citrate solutions.

The decline of the hemoglobin concentration noted in the days following was small and comparable to that noted previously. There appears to be no reason to encourage the use of erythrocytes preserved at $4^{\circ} \mathrm{C}$. in saline solution for more than a few hours for the purpose of transfusion. As a matter of fact there appears to be no good reason for resuspending the red cell 


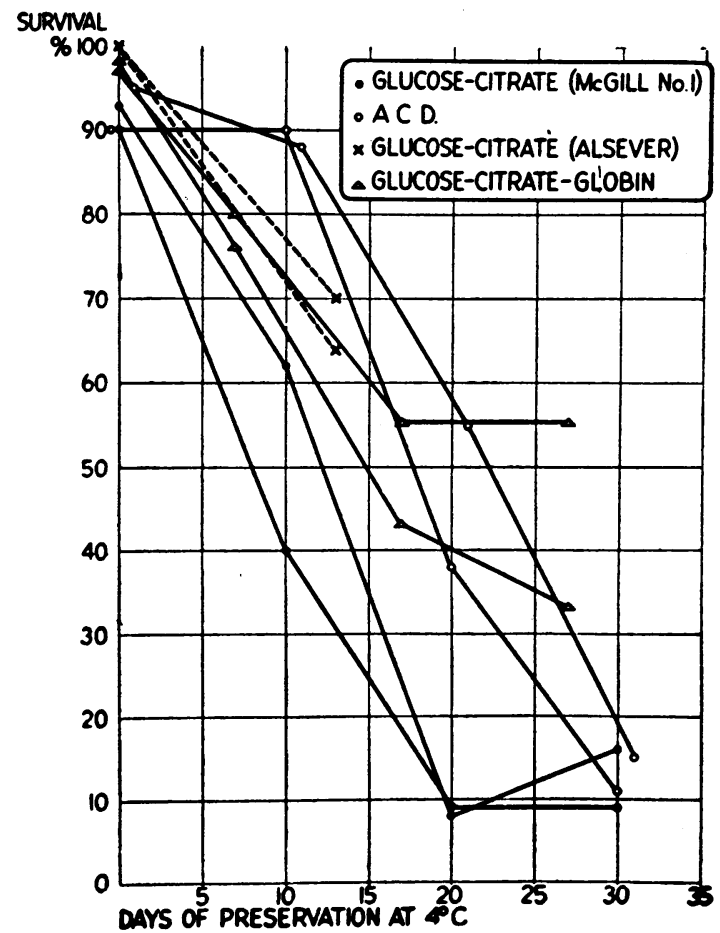

Fig. 6. Survival of Whole Blood and Resuspended ERYthrocytes in Various Solutions

residue in saline at all, as they can be transfused as they are, using an 18-gauge needle.

About 50 transfusions of 200 to $230 \mathrm{ml}$. of packed red cells, resuspended in globin solution, have been administered. Studies of the serum bilirubin content have been carried out. No hyperbilirubinemia has occurred, nor untoward reactions of any sort. The clinical results were those to be expected from well preserved cells.

\section{CONCLUSIONS}

The addition of globin in a 4 per cent concentration to an isotonic solution of dextrose-citrate increases the preservation of red cells left over from plasma preparation. With this mixture the preservation is optimal for 7 days, good up to 15 days.

\section{BIBLIOGRAPHY}

1. Strumia, M. M., Chornock, F. W., Blake, A. D., and Karr, W. G., The use of a "modified globin" from human erythrocytes as a plasma substitute. Preliminary report. Am. J. M. Sc., 1945, 209, 436.

2. Alt, H. L., Red cell transfusions in the treatment of anemia. A preliminary report. J. A. M. A., 1943, $122,417$.

3. Blum, L. L., The present-day status of combined bloodplasma bank, with reference to the use of concentrated red cell suspensions (operation and use in medium-sized hospital). J. Indiana M. A., 1943, 36, 187.

4. Blum; L. L., Red cell transfusions. J. A. M. A., 1943, 122, 892.

5. Cooksey, W. B., and Horwitz, W. H., Use of salvaged red cells. J. A. M. A., 1944, 124, 961.

6. Evans, R. S., The use of concentrated red cells as a substitute for whole blood in transfusion therapy of anemia. J. A. M. A., 1943, 122, 793.

7. Murray, C. K., Hale, D. E., and Shaar, C. M., The preparation and use of red blood cell suspensions in treatment of anemia. J. A. M. A., 1943, 122, 1065.

8. Semoff, M., Plasma and red blood cell banks for small institution. M. Rec., 1942, 155, 359.

9. Semoff, M., Red blood cells of plasma bank. Southwestern Med., 1943, 27, 248.

10. Taylor, E. S., Thalhimer, W., and Cooksey, W. B., The organization of a red blood cell transfusion service. J. A. M. A., 1944, 124, 958.

11. Watson, L., Red-cell suspension transfusions. Lancet, 1943, 1, 107.

12. Thalhimer, W., and Taylor, E. S., The transfusion of centrifuged human type $O$ cells resuspended and stored in 10 per cent corn syrup. J. A. M. A., 1945, 127, 1096.

13. Ross, J. F., The in vitro preservation and post-transfusion survival of stored blood. J. Clin. Invest., 1947, 26, 687.

14. Parpart, A. K., Lorenz, P. B., Parpart, E. R., Gregg, J. R., and Chase, A. M., The osmotic resistance (fragility) of human red cells. J. Clin. Invest., 1947, 26,

15. Karr, W. G., and Chornock, F. W., Technical note: Determination of hemoglobin in plasma (visual colorimetry). J. Clin. Invest., 1947, 26, 685. 